Mycologia, 77(1), 1985, pp. 11-16.

(C) 1985, by The New York Botanical Garden, Bronx, NY 10458

\title{
GEOTRICHITES GLAESARIUS, A CONIDIAL FUNGUS FROM TERTIARY DOMINICAN AMBER
}

\author{
SARA P. STUBBLEFIELD \\ Department of Botany, The Ohio State University, \\ Columbus, Ohio 43210 \\ CHARLES E. MILLER \\ Department of Botany, Ohio University, \\ Athens, Ohio 45701 \\ THOMAS N. TAYLOR \\ Department of Botany, The Ohio State University, \\ Columbus, Ohio 43210 \\ AND \\ GARRY T. COLE \\ Department of Botany, University of Texas, \\ Austin, Texas 78712
}

\begin{abstract}
Geotrichites glaesarius, a new fungal anamorph, is described from Dominican amber of late Oligocene or early Miocene age. A well-developed mycelium is present on the surface of an arachnid cadaver; hyphae are not present in the body cavity. Septate hyphae are either erect or decumbent, and extensively branched. Oblong arthroconidia are borne terminally on undifferentiated hyphae. Conidiogenesis appears to be of the holoarthric type with conidia sometimes joined by narrow connectives. The fungus is apparently saprophytic and resembles several modern moniliaceous fungi, particularly Geotrichum candidum.
\end{abstract}

Key Words: amber, Dominican Republic, fossil, Moniliales, saprophytism, Tertiary.

Fossilized resins, popularly known as ambers, are of considerable interest both economically and scientifically. The most extensively studied is the Baltic Eocene amber from which a wide variety of plant and animal remains have been reported (Larsson, 1978). Fossiliferous amber is also known from numerous sites in the New World ranging in age from the Carboniferous to the Pleistocene (Langenheim, 1964), and is probably most well known from Chiapas, Mexico (see Langenheim, 1966). New World amber is also known from the Dominican Republic (Sanderson and Farr, 1960), but it has not been studied extensively. Little is known about animal remains within this amber and even less attention has been paid to the plant inclusions. The presence of fossilized plant remains has been noted briefly (Sample, 1905; Sanderson and Far, 1960), but the only detailed reports are the recent descriptions of an entomophthoraceous fungus (Poinar and Thomas, 1982) and a grammitid fern (Gomez, 1982). In the present study, a well-preserved conidial fungus growing on an arachnid is described from a piece of amber from the Dominican Republic. 
A single specimen of amber containing a well-developed mycelium on an arachnid cadaver was identified from a larger collection of material from the Dominican Republic. Dominican amber was originally reported from two localities (Sanderson and Far, 1960), and Rice (1981) refers to at least a dozen mines. However, the problem of inadequate locality information is frequently encountered in the literature dealing with amber (Skalski, 1975) and the precise origin of the present material is unknown. Because Dominican amber has apparently been reworked, there is some uncertainty regarding its stratigraphy. It has been placed in the Oligocene (Sanderson and Farr, 1960) or in the early Miocene (Langenheim, 1969).

A small fragment containing the fungus was cut from a larger block and ground to a thickness of approximately $2 \mathrm{~mm}$ on 600 grit carborundum. It was further ground on allumina and finally polished with "ZAM" (product of GFC, Carlstadt, New Jersey 07072), a fine buffing compound. When the desired thickness and polish had been obtained, the specimen was examined and photographed directly using transmitted and reflected light. Because of the thickness of the material and the yellow color of the amber, contrast in photography was enhanced using Kodak Contrast Process Ortho film. The specimen is housed in the Paleobotanical Herbarium of Ohio University.

\section{SYSTEMATICS}

Geotrichites Stubblefield, Miller, Taylor, and Cole, gen. nov.

Hyphae aerial, erect or decumbent, septate, sometimes branching dichotomously. Conidiophores micronematous. Conidia holoarthric, nonseptate, produced by schizolytic disarticulation, variable in size, oblong or truncate with obtuse ends. Fossil.

Type species: Geotrichites glaesarius.

Geotrichites glaesarius Stubblefield, Miller, Taylor, and Cole, sp. nov. FIGS. $1-7$

Characteristics as in generic diagnosis. Hyphae 2-5 jum wide. Conidia (3-)5$9(-15) \times(2-) 3-4(-5)$ [i m (100 measurements). Adjacent conidia joined by narrow connectives. On arachnid cadaver from Dominican Republic amber.

\footnotetext{
HOLOTYPE: Specimen 7663 in the Paleobotanical Herbarium of Ohio University, Athens, Ohio. Miocene.

TYPE LOCALITY: Dominican Republic, precise location unknown. Age: Late Oligocene or early

ETYMOLOGY: glaesarius $(L)=$. of amber.
}

A well-developed mycelial mat is present on the dorsal surface of an arachnid cadaver (FIGS. 1, 4). Hyphae cover most of the arachnid, but are not present within the body cavity. Hyphae are aerial, erect or decumbent, and septate and branch extensively (FIG. 5), sometimes dichotomously. Hyphae are sometimes clear, but most often show alternating dark and light areas (FIG. 6). Conidia are borne terminally from unspecialized hyphae (FIGS. 2, 3, 7).

FIGS. 1-7. Geotrichites glaesarius. 1. Ventral surface of arachnid cadaver, X22. 2. Hyphae and chains of conidia, X420. 3.Hyphae and chains of conidia, X260. 4. Mycelium obscuring arachnid, X27. 5. Branching hyphae and scattered conidia, X420. 6. Individual hypha with internal dark and light regions, $\mathrm{x} 300$. 7. Chain of conidia with narrow connectives (arrows) between some conidia x 850 . 


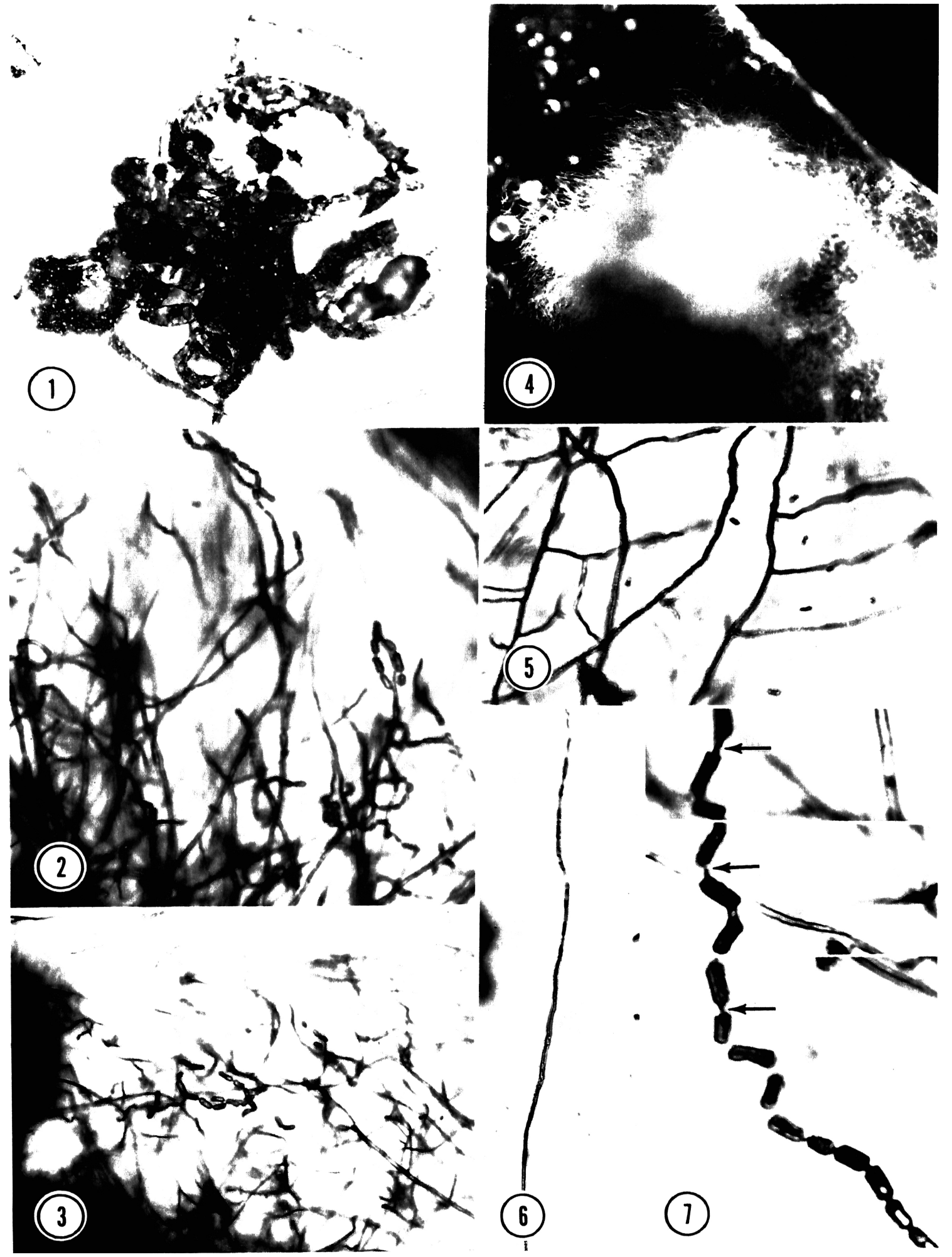




\section{DISCUSSION}

The association of Geotrichites glaesarius with an arachnid cadaver raises the possibility that it is a pathogenic or parasitic fungus. This, however, seems unlikely because the body cavity of the arachnid contains no evidence of fungal invasion. Rather, it is more probable that it is similar to one of a wide variety of extant common molds which are opportunistic saprobes, colonizing arthropod cadavers and other substrates (see Roberts and Humber, 1981, for a classification of types of fungus-insect associations). The distribution of conidia in the amber suggests that the arachnid, already infected with the fungus, was trapped in flowing resin. The morphology of the present fungus suggests that it is a form previously unknown in the fossil record and that its affinities lie with the moniliaceous members of the Deuteromycotina (Barnett and Hunter, 1972).

Although moniliaceous fungi have not been described from Dominican amber, a number of Cenozoic ambericulous fungi are known. They are represented by the following taxa listed as originally cited: Penicillium curtipes Berk., Ramularia olbongispora Casp., Torula heteromorpha Casp., Sporotrichites heterospermus Goepp. and Berendt, Gonatobotrys primigenia Casp., Acremonium succineum Casp., Monilites Pampaloni, Fusidium Conwentz, Stilbum succinii Casp., Oidium moniliformis Menge and Goepp., Cladosporium sp. Conwentz, Streptothrix spirilis Berk, and Brachycladium thomasinum Berk. Of these, Sporotrichites heterospermus, Stilbum succinii, and Botrytis similis were associated with insects. Geotrichites glaesarius differs from each of the preceding taxa either in branching, conidial shape and size, conidial arrangement, or conidiogenesis. The present material also differs from the only other fungus known in Dominican Republic amber. That unnamed fungus produced budding, subellipsoidal primary conidia and spherical, secondary conidia and was assigned to the Entomophthorales (Poinar and Thomas, 1982).

Geotrichites conforms to the modern genus Geotrichum Link ex Pers. in most aspects, although it is impossible to determine whether or not the mycelium is dry or slimy in the fossilized state. The genus Geotrichum has had a complex taxonomic history (Morenz, 1964; Sigler and Carmichael, 1976), and presently includes species related to the yeasts as well as those described as arthroconidial states of member of the Basidiomycotina (Sigler and Carmichael, 1976). Among extant species of Geotrichum, G. glaesarius is strikingly similar in its morphology and its saprobic habit to $G$. candidum Link ex Pers., a common conidial, soil fungus of word-wide distribution (Carmichael, 1957; Barron, 1968; Sigler and Carmichael, 1976; von Arx, 1977,1981). Geotrichum candidum and G. glaesarius share many morphological similarities including a simple thallus, similar substrates, and holoarthric conidiogenesis.

Carmichael (1957) studied 52 strains of Geotrichum candidum from diverse geographical areas and varied substrates. He isolated strains from sputum, feces, skin, and mouth, probably of human origin, and milk, cheese, treatment filters, sulfite waste, spoiling banana and cucumber, slime mold cultures, and soil. Lacy (1981) reported colonization of cold, moist humidifiers by Geotrichum, and Hawksworth (1981) reported G. candidum among several fortuitously-occurring conidial fungi growing on the sclerotia of Rhizoctonia solani. The arachnoid cadaver on which Geotrichites was growing fits well into the substrate range of $G$. candidum. Carmichael (1957) also grew 52 strains of $G$. candidum on a variety of media and demonstrated that conidial size varies with substrate. It is not surprising that conidia of the amber fungus are, on the average, smaller than those obtained from $G$. candidum grown on several different media, since arachnoid cadavers probably have limited nutrients compared to the nutrients present in 
the artificial media. Nevertheless, the range of conidial sizes in G. glaesarius is well within the lower range of conidial sizes in $G$. candidum.

Although Geotrichum candidum is a superficially similar modern analog to Geotrichites glaesarius, there are differences both in morphology and conidiogenesis. The conidia of G. glaesarius are more elongate and less barrel-shaped than those of G. candidum. They are perhaps more similar in shape to those of the Geotrichum anamorph of Endomyces magnusii Ludwig (Cole and Kendrick, 1969; pi. III). However, the connectives seen between conidia in G. glaesarius are absent in both of these species of Geotrichum (Cole and Kendrick, 1969; Cole, 1975). Although such structures are known in several species of Oidiodendron (Barron, 1962; Cole and Kendrick, 1969; Cole, 1975) these fungi differ greatly from $G$. glaesarius in branching.

Probably the most characteristic feature of $G$. glaesarius is the presence of chains of conidia formed by the septation and fragmentation of terminal regions of undifferentiated hyphae. This type of conidium formation has been described in a number of extant fungi and is referred to as holoarthric conidiogenesis (Cole, 1981). The extensions between adjacent conidia are strikingly similar to the narrow connectives which have been seen between adjacent holoarthric conidia in species such as Oidiodendron truncatum (Robak) Barron (Cole and Kendrick, 1969). Cole and Kendrick (1969) speculate on the composition of the connectives and, like Barron (1962), conclude that they are most likely "more or less gelatinous." In light of this interpretation it is surprising that these areas are apparently as well preserved as the adjacent conidial wall tissue in Geotrichites. The order of conidia formation is also of some interest (Cole and Kendrick, 1969). Although evidence is insufficient to indicate the order of septation in the present material, it is clear from the positions of isolated conidia and those joined by connectives that fragmentation was neither strictly acropetal nor basipetal. Random fragmentation has also been documented in G. candidum (Cole and Kendrick, 1969).

Because fossil moniliaceous fungi are represented in other Cenozoic deposits the presence of an organism like Geotrichites glaesarius is not unexpected in Dominican amber (e.g., Berkeley, 1848; Goeppert, 1853; Conwentz, 1890; Pampaloni, 1902; Caspary, 1907; Pia, 1927; Czeczott, 1961). However, its discovery increases our knowledge of the diversity of conidial fungi, as well as the diversity of the Dominican amber flora. Furthermore, it documents a developmental process, holoarthric conidiogenesis, and demonstrates that conidial connectives were in existence some 30 million years ago.

\section{ACKNOWLEDGMENTS}

The authors wish to thank Dr. Gene K. Mapes of Ohio University, Athens, Ohio, who brought this fungus to our attention and loaned the specimen, and Dr. Gar W. Rothwell also of Ohio University for assistance with photography. The research was supported by the National Science Foundation (DEB-8213060).

\section{LITERATURE CITED}

Arx, J. A. von. 1977. Notes on Dipodascus, Endomyces and Geotrichum with the description of two new species. Antonie van Leeuwenhoek 43: 333-340.

1981. The genera of fungi sporulating in pure culture. Cramer, Vaduz. $424 \mathrm{p}$.

Barnett, H. L., and B. B. Hunter. 1972. Illustrated genera of imperfect fungi. Burgess Publishing Co., Minneapolis, Minnesota. 241 p.

Barron, G. L. 1962. New species and new records of Oidiodendron. Canad. J. Bot. 40: 589-607. 364 p. 1968. The genera of hyphomycetes from soil. Williams and Wilkins Co., Baltimore, Maryland. 
Berkeley, M. J. 1848. On three species of mold detected by Dr. Thomas in the amber of East Prussia. Ann. Mag. Nat. Hist. Ser. 2 2: 380-383.

Carmichael, J. W. 1957. Geotrichum candidum. Mycologia 49: 820-830.

Caspary, R. 1907. Die flora des Bernsteins und anderer fossile Harze der Ostpreussischen Tertiars. Preus. Geol Landes. N. S. 4: 1-181.

Cole, G. T. 1975. The thallic mode of conidiogenesis in the Fungi Imperfecti. Canad. J. Bot. 53: 2893-3001.

. 1981. Conidiogenesis and conidiomatal ontogeny. Pp. 271 -327. In: Biology of conidial fungi. Vol. 2. Eds., G. T. Cole and B. Kendrick. Academic Press, New York.

, and W. B. Kendrick. 1969. Conidium ontogeny in Hyphomycetes. The arthrospores of Oidiodendron and Geotrichum, and the endoarthrospores of Sporendonema. Canad. J. Bot. 47: 1773-1780.

Conwentz, H. 1890. Monographie der baltischen Bernsteinbaume. Engelmann, Danzig. 151 p.

Czeczott, H. 1961. The flora of the Baltic amber and its age. Prace Muz. Zeimi 4: 119-138. (English translation: ibid., 139-145.)

Goeppert, H. R. 1853. Ueber die Bernsteinflora. Monatsber. Konigl. Preuss. Akad. Wiss. Berlin 60: 1-28.

Gomez, L. D. 1982. Grammitis succinea the first New World fern found in amber. Amer. Fern J. 72: 49-52.

Hawksworth, D. L. 1981. A survey of the fungicolous conidial fungi. Pp. 171-244. In: Biology of conidial fungi. Vol. 1. Eds., G. T. Cole and B. Kendrick. Academic Press, New York.

Lacy, J. 1981. The aerobiology of conidial fungi. Pp. 373-416. In: Biology of conidial fungi. Vol. 1. Eds., G. T. Cole and B. Kendrick. Academic Press, New York.

Langenheim, J. H. 1964. Present status of botanical studies of ambers. Bot. Mus. Leafl., Harvard Univ. 20: 225-287.

1966. Botanical source of amber from Chiapas, Mexico. Ciencia (Mexico) 24: 201-210.

1969. Amber: a botanical inquiry. Science 163: 1157-1169.

Larsson, S. G. 1978. Baltic amber-a palaeobiological study. Entomonograph 1. Scandanavian Sci. Press, Klampenborg. 192 p.

Morenz, J. 1964. Taxonomische Untersuchungen zur Gattung Geotrichum. Mykol. Schriftenreihe 2: 33-64.

Pampaloni, L. 1902. I resti organici nel disodile de Melilli in Sicilia. Palaeontographia Italica 8: $121-130$.

Pia, J. 1927. Thallophyta. Pp. 31-136. In: Handbuch der Palaobotanik. Ed., M. Hirmer. R. Oldenbourg, Publ., Miinchen and Berlin.

Poinar, G. O., and G. M. Thomas. 1982. An entomophthoralean fungus from Dominican amber. Mycologia 74: 332-334.

Rice, P. C. 1981. Amber mining in the Dominican Republic. Rocks and Minerals 56: 145-152.

Roberts, D. W., and R. A. Humber. 1981. Entomogenous fungi. Pp. 201-236. In: Biology of conidial fungi. Vol. 2. Eds., G. T. Cole and B. Kendrick. Academic Press, New York.

Sanderson, M. W., and T. H. Farr. 1960. Amber with insect and plant inclusions from the Dominican Republic. Science 131: 1313.

Sample, C. C. 1905. Amber in Santo Domingo. Eng. Mining. J. 80: 250-251.

Sigler, L., and J. W. Carmichael. 1976. Taxonomy of Malbranchea and some other Hyphomycetes with arthroconidia. Mycotaxon 4: 349-488.

Skalski, A. W. 1975. Notes on present status of botanical and zoological studies of ambers. Studi e rioerche sulla problematica deU'ambra 1: 153-175. 